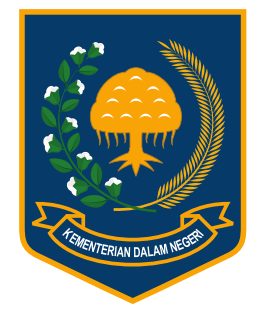

Jurnal Bina Praja 8 (1) (2016): 149-161

Jurnal Bina Praja

e-ISSN: 2503-3360 | p-ISSN: 2085-4323

Accreditation Number

735/AU2/P2MI-LIPI/04/2016

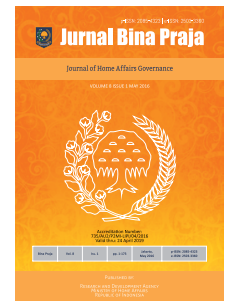

http://jurnal.kemendagri.go.id/index.php/jbp/index

\title{
The Relation Between Multi Actors AND LOCAL REFORM IN SOLO CITY DURING JOKO WIDODO'S LEADERSHIP ERA (2005-2012)
}

\author{
Wahidah R. Bulan ${ }^{1}$ \\ ${ }^{1}$ Department of Communication Studies, Universitas Pembangunan Nasional "Veteran" Jakarta \\ Jl. Raya Fatmawati Jakarta Selatan
}

Received: 1 February 2016; Accepted: 19 May 2016; Published online: 31 May 2016

\begin{abstract}
This study explored power relation of Jokowi as mayor of Solo City and his efforts to create inclusive populist policies in the case of street vendors' arrangement and resettlement of people on the banks of Solo River. Specifically, this study explores how Jokowi build his relations with many actors, namely, how the relations can be established, who were they, how were the relationships between Jokowi and CSO (Civil Society Organization) and CSA (Civil Society Activist) as the agencies with serious interest in pursuing reform, and how these relations contribute to achieving local reform agenda. By using qualitative approach with case study strategy as the methodology, this study was conducted from December 2010 to early 2012 and obtained some results as follows: there are some strong enough relations between Jokowi with state and non-state actors, which exist as the attempt to overcome the structural constraints (limited human resources) and because of the similar agendas between Jokowi and those actors (especially with CSO and CSA), and that the relations (with CSO and CSA) are proven effective in helping to achieve local reform agenda progressively. The study also refines Tilly's theory (1978) on several aspects, namely: the variant of member and challenger, the radical challenger, and neutral, and that the positions of challenger or member are not permanent (depend on the issues).
\end{abstract}

Keywords: local reform, power relation, the regional heads, civil society activist (NSA), member; challenger.

\section{INTRODUCTION}

While noting that not all regional heads are capable of seeking reform even with the same authority (article 21 of Law No. 32/2004), the authority factor (hard power) proved inadequate to drive a change. Needed soft power such as courage, capability to make a change, capability to innovate, including the capability to build relation with multiactors to create reform (Bulan, 2013); or what Tanri Abeng (2012) called as Seven C of leadership power sources, namely: clever, courageous, competent, clean, committed, carrying, dan communicative.

One of those is related to the ability to build relationships with multi-party, which is based on the preliminary study conducted the author as one of the success factors of Jokowi-Rudi in creating local reform agenda in Solo. This was done through a number of activities arisen from the Javanese tradition popularized by the term SLJJ, namely: sonjo (friendship), layat (go to the person whose family members died), Jagong (meet the invitation), and Jagongan (discussion or deliberation). If the activities of sonjo, layat, and jagong are conducted in the form of coming to the people or figure (come to invitations of wedding, circumcision, and to intentionally do Friday prayer and Maghrib prayer in certain Islamic boarding school (pesantren) or mosque; jagongan is conducted in the form of formal activities of "Rembug Kampung" (public communication forum at village level), "Rembug Kuto" (public communication forum at city level), "Mider Projo" (going around the city) every Friday morning, Reflection of Joko-Rudi (annual event to hear the opinion or assessment of people on the performance of City Government), or "Meet Mister Meyer" (talk show between Mayor and High School students held in coordinating with Solo Radio).

In addition, Jokowi also developed what he called as FGD (Not Focus Group Discussion but Forum Group Discussion), which is a forum where Jokowi interacts with multi-stakeholders. If the activities of SLJJ are intended to determine the

\footnotetext{
* Corresponding Author

Phone : +6281287795651

Email : wr.bulan@gmail.com
} 
conditions in the field (gathering public aspiration), FGD is conducted to formulate alternative solutions / policy on a variety of issues that require immediate attention or that received widespread attention.

About why those things are done, Jokowi said that he realizes the limitations of his knowledge (and bureaucracy) to the problems or policies that will be put forward.

"For example, we want to establish a market. I don't know anything about the market. What are the problems? What are the issues? If we want to establish a market, what is the direction of the door ? How many kiosks it needs ? I don't know. The persons who know about all these are the vendors as the actors. Then we get them to talk with us. We gather them. Then they give us alternatives. There is alternative one, two, three... I just want to execute the chosen alternative..." (Interview with Jokowi on December 30, 2010).

In the preliminary study was also found Jokowi's special relation with a number of Civil Society Activists (CSA) in Solo City, which is done by involving them in the management of power (making them the inner-circle). "I have an expert staff of non-civil servant, special staffs unknown to the public, which often gives voice (input, author) to me. This one over here is still bad, the not good enough is over here ... "(Interview with Jokowi on December 30, 2010). Jokowi referred them as nonformal expert staffs because there are no formal ties which show the rights and obligations of each party in the relation.

As for why the relation can be established, it is because of Jokowi's dissatisfaction against bureaucratic work which, according to him, prefer to deliver the information wanted by the leader and not the real information about the condition of the field. "... Bureaucracy tends to only deliver good information ... So that I'm happy ... While in fact I want to know the real conditions ..." (interview with Jokowi on December 30, 2010).

Although community involvement in the decision-making process as done by Jokowi is actually a conventional thing, in fact it has become a new trend in public service management such as the New Public Service, which is a model of public service management that gives priority to the importance of citizen engagement (Osborn, 1992; Ferlie, 1997; and Denhardt, 2003), but people often complain that they are often consulted by the government without having to be seen whether their opinion would be used or not.

Another complaint is that they are often gathered only as a means of legitimacy that the state has opened the space for participation. At least that is the complaint often submitted by the stakeholders in the process of netting input through Musrenbang and it is also the underlying reason why some NGOs refused to attend the dialogue forums. At least that is what happened on why some NGOs refused to attend and form a Cross Actors Forum at National level in the case of Social Security Network. They are reluctant to open dialogue because they consider that the government has the forum just to meet loan requirements of the World Bank (Suharko, 2005).

In the context of democratization, community involvement in policy making and in solving the real problem is the duty of state given the power "owned" by the state is only "entrusted" by the people as the real owner of sovereignty. But because of frequent abuse of power by the state with no use of power according to the mandate of the people, various conflicts often happen between them. Hence, the resistance of civil society as an active party in voicing the setting limits on the power of State (Buci-Glucksmann, 1980) also must be seen in that context, namely as a reaction to the action of the hegemony of states that emerged with the armor of coercion (hegemony protected by the armor of coercion).

Consequently, the resistance of civil society as an active party in voicing the setting on the power of State limits (Buci-Glucksmann, 1980) also must be seen in that context, namely as the reaction to the hegemony action of state that emerged with the armor of coercion (hegemony protected by the armor of coercion).

This is the focus of the study, which explores how Jokowi's relation can be established with multiactors in the process of reform in Solo, particularly with the CSO and CSA, and how the relation can contribute to the efforts to achieve reform agenda. Studies on the subject are relatively limited (especially in the context of local reform), while the need to study is increasing given the change in relation management between actors (structural or non-structural) post-reform. For example, changes in the relation between regional head and DPRD that is relatively equal while before DPRD is positioned to be part of the local government; as well as state relation with the CSO and CSA, which now does not always appear in the vis a vis format.

Although there are a number of studies on the relations between the actors, very few studies that specifically addressed the relation of the regional head with multi -actors and more specifically with the CSA. One that is somewhat relevant is the study of the relation between actors in Jembrana District (Jembrana Health Insurance innovation case or JKJ) and Kebupen District (Village Fund Allocation case or ADD), conducted by AKATIGA (2009). But while exposing multi-actor relations, including relation with regional head, the standpoint of the study is more on non-state actors (CSO and CSA) considering the study was conducted within the framework of the strengthening of civil society. 
Other studies worth mentioning are the study by Suharko (2005), which discusses the relation of NGOs with the government in developing democratic governance by taking the case of the implementation of Social Safety Net (JPS) program, the study by Ganie Rochman (2002) about the role of NGOs (advocacy) amid authoritarianism of New Order, the study by Eldridge (1995) who tries to find an overview of the core values and aspirations of NGO and the operational relations with their assisted groups as well as their interaction with government agencies, as well as study by Hadiwinata (2003) who conducts an analysis of strategic changes that occur on local NGOs (including their relationship with the state) as a result of changes in national political conditions.

However, considering that those studies were conducted during the authoritarian regime of New Order, the studies tended to put non-state actors (in this case the NGO) in a central position while the state was depicted as negative figure (bad state), namely as the side that did not support the democratization process (restrict the movement of people and nonparticipatory). Considering that post-reformation the emergence of good state began to develop as a new phenomenon, the study to explore the role of government (especially regional head) in driving a change becomes more important to be conducted.

Another thing to be considered is that the existing studies emphasize more on the analysis of the relationship between state actors (regional government, DPRD, and bureaucracy) with institutional actors (NGOs and CBOs) and less on the involvement of individual actors such as the instigators of civil society or civil society activist (NGO activists, leaders, professionals, academics, etc).

Given the occurrence of the increasing the role of individual actors phenomena as the positive impact of democratization (cases of Refli Aaron, Macica Mochtar, etc.) as well as the impact of information technology development (case of coin for Prita), the study on the relation of regional heads and multi-actors, including individual actors, is perceived more as a necessity. Related to that then (one of) the formulation of research problems of this study is how the relation between local actors in the process of reform in Solo City. Related to that, the issue that will explored in this study is about: with whom Jokowi build a relation, how the relation can be established, and in the context of relations between Jokowi and CSA and CSO as the agencies with quite serious efforts to reform, how these relations can effectively achieve reform agenda to a more progressive direction. Given the relation also occurs between non-state actors (CSO and CSA), also explored the relation between CSOs and between CSA and between CSO and CSA in the

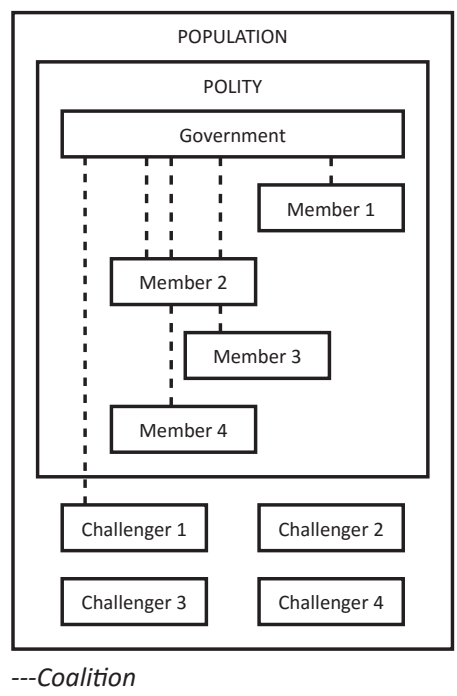

Figure 1. The Polity Model

governance of the relation.

\section{METHOD}

The study is conducted using a qualitative approach, which is to explore the relation between regional head and multi-actors in the effort of the regional head as reform main actor to achieve changes (Creswell, 1994). While it refers to the four traditions of sociology (Berger, 1963), the study focused on trying to understand the actor's action (social action), which is the pattern and consequences of the actor's action, both intended and unintended consequences of purposive human action, in this case the action of regional head actor to build relation with multiple actors in order to achieve his development agenda.

Social practice is presented through the depiction of holistic reality condity with the collection of words based on detailed reports of informants arranged with scientific background (Creswell, 1994), which includes detailed and accurate information on the phenomenon being studied, the background and context of the situation, the documentation of the running process or mechanism, as well as clarifying the running stages and finding an effective relation model (Newman, 1999: 21-22).

Data collection is conducted with the case study method given that the researcher intends to understand the issues in depth, which is explored through two selected cases (arrangement of street vendors and resettlement resident banks of the Solo River) and performed within certain limits (multiple bounded systems) are the peculiarities of the social system, culture and politics Solo and a certain time, in this case the leadership as Solo Mayor Joko Widodo (2005-2012) (Cresswell, 2007: 73). The study began in June 2010, when the author 
conducted a preliminary study in order to obtain a complete picture of the condition of the field and reinforce the developed assumptions, until the need for data requirements was sufficient in December 2012.

The theory used to understand the dynamics of power relations between the regional head and multi-actor used by the researcher is the Polity Model, which is the first part of the model of collective action (Tilly, 1978). The Polity model describes the interaction between group with a group of collective action consisting of the population , a government, one or more contender where there are members or supporters and challenger or the opposition, a policy (a collective action that occurs between members of the government), and one or more contender where there are member or supporter and challenges or opposition, a policy (a collective action that occurs between members of the government), and one or more coalition.

Regarding the relation between regional head and multi-actors as described in the polity model (Figure 1), it occurs because of the efforts of member and challlenger to compete for a position in polity, in order to exercise control over resources with the aim of increasing ownership of resources. By using the available resources, the challenger looks for ways to be "pushed" into the policy, while member tries to take the fight in order to secure its position. That contestation allows the shift of position, so that those who initially become opposition may turn into member and vice-versa, member can be challenger, or if they get out of the policy, its relationship with the government can be "stretched" or "away" (e.g. from the ring one to bring two).

\section{RESULT AND DISCUSSION}

Referring to the Polity Model (Tilly, 1978) about the existence of parties that become member and challenger in the context of power management (policy), there are a number of actors with whom Jokowi build his relation, both in the effort to reform in Solo City in general and in the case of the arrangement of street vendors and transfer of population from the banks of the Bengawan Solo River.

For relations with state actor (Deputy Mayor of Solo, bureaucracy in Solo City Government and Solo City DPRD), the relation is relatively with little change, although with slightly different levels of support. The highest support is given by Rudy as Vice Mayor, who since his early work "help" Jokowi in an all-out manner. Bureaucratic support is one level below it, because even though bureaucracy is formally responsible for carrying out the action reform of regional head, but the internal resistance of bureaucracy is still found (in the case of street vendors is the Office of PPKL which later became the Department of Markets and street vendors as well as municipal police; while for the transfer of population from Bengawan Solo river bank are Bapermas, DTRK, DPU, municipal police). The resistance which occurs due to changes in the approach is done by the main actors of reform (Jokowi) on policing approach to empowerment approach and from violence approach to nonviolence approach. Regional head's own approach is required to "conquer" the bureaucracy so that it is willing to work in line with expectations and ways as set by regional head (Jokowi), namely by showing exemplary; socialization of the vision, mission, and the policy to strive for; up to rather forcefully action in the form of bureaucratic mutation (executed by Jokowi to four urban-village heads and a district head). Besides, resistance also occurs because Jokowi make rooms for parties to become challenger to discuss the policy, even make room for policy changes, which for bureaucracy cause discomfort (policy is considered unable to be implemented quickly, policies that are unpredictable or uncertain, and some bureaucrats consider it causing the dignity or authority of the bureaucracy weakened).

DPRD, especially those from the PDIP faction, are members whose support quality is equivalent to Rudy, given their position as the supporting political party. However, because the DPRD is also faced with a position as power control (supervisory function), in the practice of critical actions such as inquire and question the reform policy of regional head, also found coming from the PDIP faction.

While legislators from non-supporting parties, considering that street vendors become a crucial issue in Solo City, nearly all have a single attitude that is to approve policies. Some of the objections submitted by DPRD are more related to the amount of the budget that should be allocated from the budget for the implementation of the policies and critical view of the relocation technical fix (arrangement of street vendors). Therefore, it can be said that there are no extreme differences between the attitudes of supporting and non-supporting political parties (both are in the position of the member) despite different levels of support (support of PDIP faction is a level higher than the support of other factions). For the case of transfer of population from the banks of the Bengawan Solo River, the condition is somewhat different, in which the resistance of DPRD in the early stages is relatively little strong, although not up to showing the opposing attitude, both from PDIP and not-PDIP. Related to that, DPRD is more appropriate to be positioned as a critical member, which is the member who is critical of the most dominant stance as a supporter (member). Another thing is if in the early stages of reform the critical attitude is relatively high (although lower than the attitude of support), at the final stage of reform, the 
critical stance declined considerably.

Then, how is Jokowi's relation with the CSA, namely those by Jokowi are called non-formal expert staffs (PG, AN, and ES)? Jokowi's relation with CSA relatively has not changed in because from the beginning they are positioned as a member, even the major supporters of Jokowi (inner circle). The full support that is mainly given because of agenda compatibility between the CSA and Jokowi, so that CSA is willing to provide full support despite not getting any resources or economic profit, even they stated of not wanting the support provided with the "pay" with practical economic interests.

The "exchange" for the support is given by Jokowi more by placing them as key partner, specifically as a place to ask questions, discuss, and even laments, which is possible given that the CSAs who became the informal expert staffs are those who have experience (competencies) and quite good support base on the issues that top Jokowi's reform agenda (including the issue of street vendors arrangement and transfer of population from the riverbanks).

Relation change is more visible on Jokowi's relation with CSOs. If at the beginning of reform most of the CSOs are in a position of the challenger, with the reform policy reform, they are undergoing drastic changes with the number of NGOs move to become a member. The change happens because of the reform agenda similarity between Jokowi's agenda and CSO's agendas, namely to pursue inclusive populist policy both for street vendors and people of Bengawan Solo's Riverbanks, which are generally the groups assisted by CSO. Besides, the approach of the reform's main actors that is willing to open a discussion space (sharing of power) by making some policy changes to accommodate the interests of NGOs (and their target groups), make a number of NGOs willing to shift from challenger into the member. Additionally, the change is also due to the help of a number of NGOs which already joined as a member.

The illustration of Jokowi's relation with multiactors in the case of street vendors as well as transfer of population from riverbanks in the early stages, which is before the reform policy is implemented and after the policy is implemented, can be seen in Figure 2.

Furthermore, also found some parties that keep their distance from the existing relation pattern taking the position outside the policy as conducted by university that despite actively contribute its ideas but do not position itself as the party that supports or rejects and the mass media (Daily Solopos) which although actively make room for opposition parties, more in terms of maintaining the balance of news, namely the need to cover both sides in the news and not for the support to the opponents; and therefore, it is also why the media gives the same space to the Mayor and Deputy Mayor. The media seems to maintain its independence on the conflict.

Another important point is the relation between the government and multi-actor that is not permanent in the sense that for a certain policy, it may be that a particular actors choose the position as member but decline the other policies, although

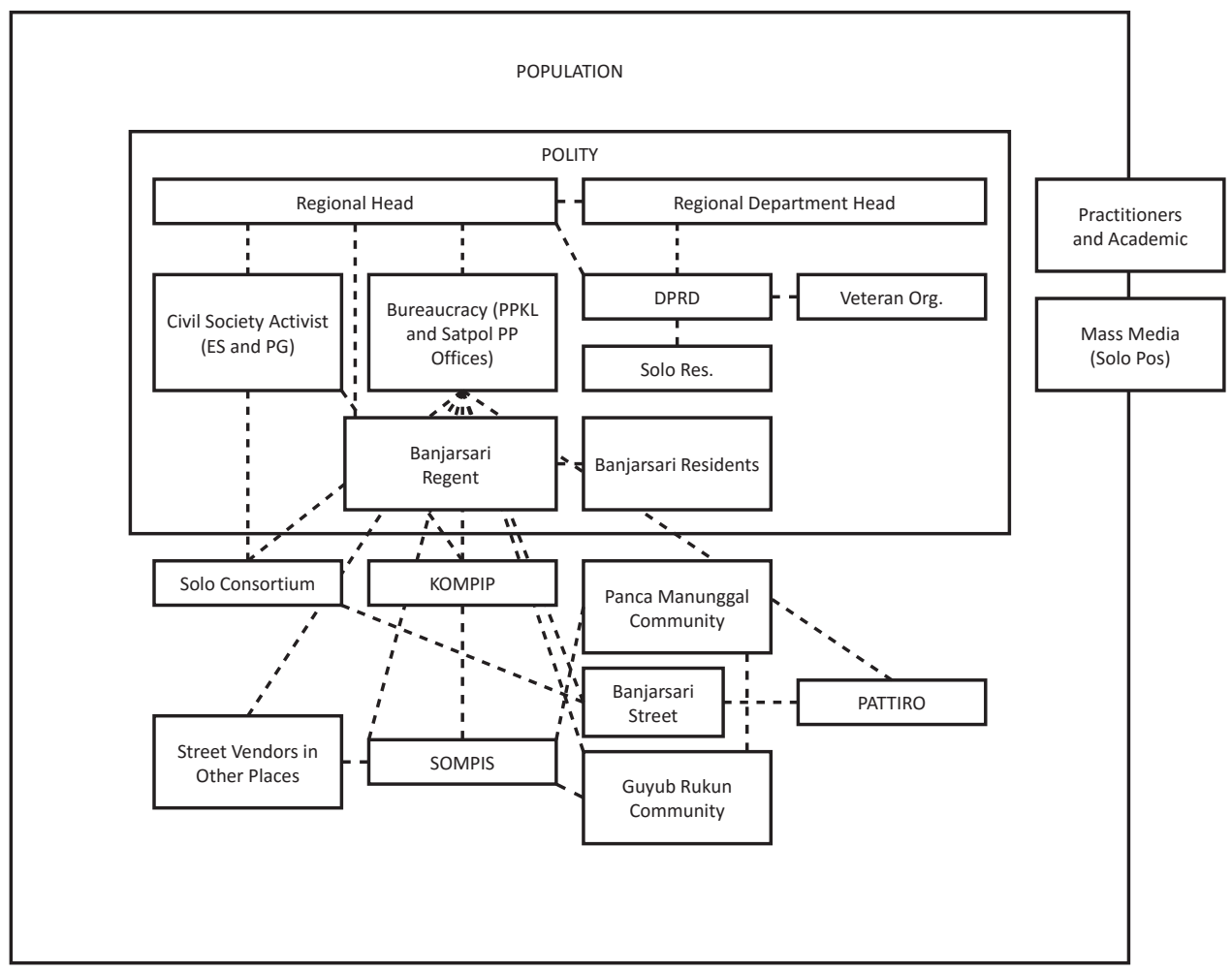

Figure 2. Jokowi's Relation with Multi-actor before Reform Policy (Street Vendors Case) 


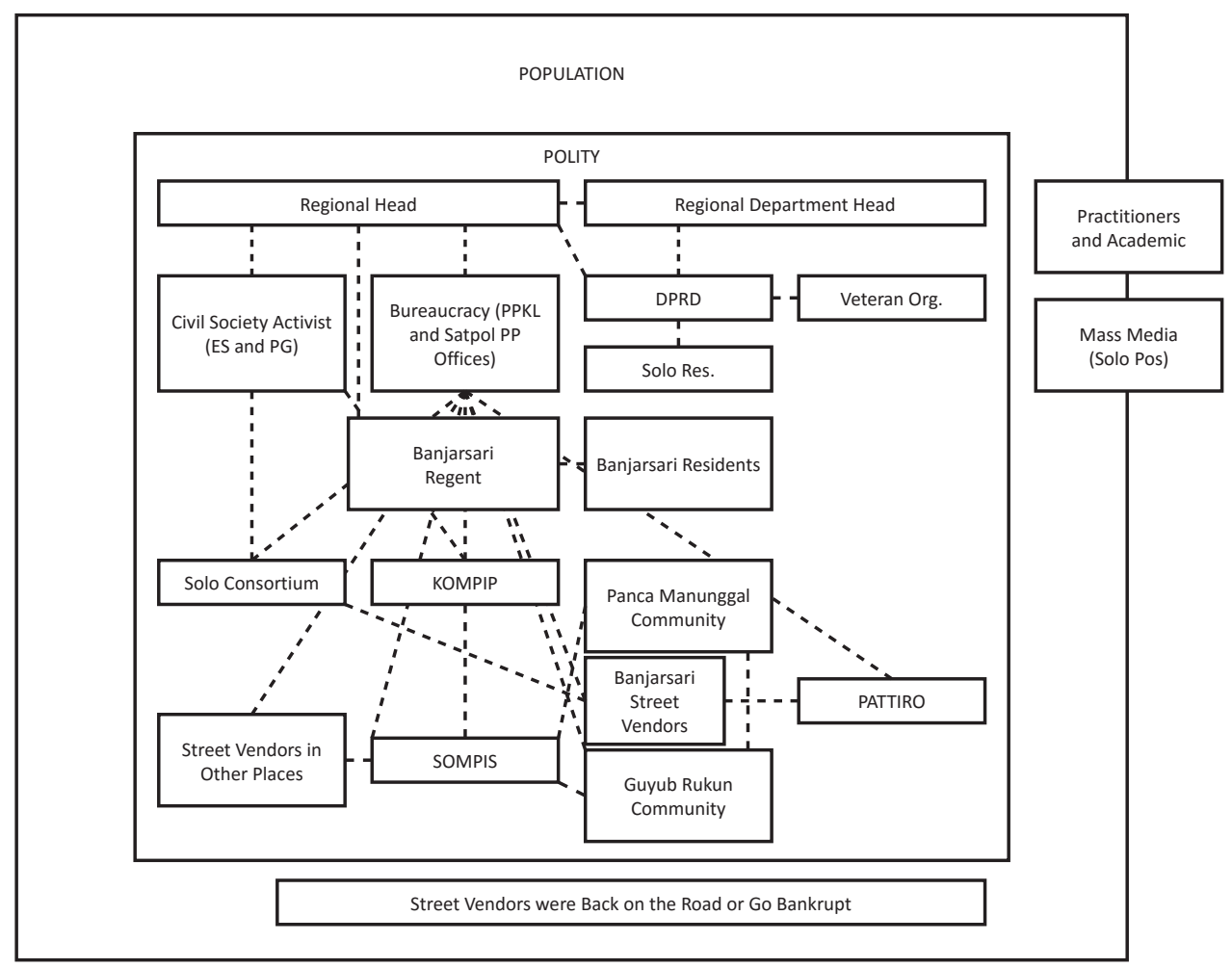

Figure 3. Jokowi's Relation with Multi-actor in Street Vendors Case (After Relocation)

there are also those who remain as member on many occasions (bureaucracy, CSA and Deputy Mayor) and likewise with the challenger. For example, some of the challengers to the street vendors' relocation policy turn into the member, but for the implementation of the new local regulation as the substitute of Regulation No. 8/1995 (mainly related to the imposition of fines and Solo ID Card for street vendors), the majority still took opposing positions. After street vendors' relocation policy, there is still a challenger, namely the street vendors who had followed the relocation but eventually returned to the road (become street vendors again), which occurred when their business failed and regard it as a result of the street vendors' relocation policy.

Referring to the Polity Model (Tilly, 1978), which stated that the people involved in the management of power are located in two extreme poles (member and challenger), this study shows that in the two cases studied, the relations are always dichotomous. There are actors outside both positions, which are neutral or keep their distance

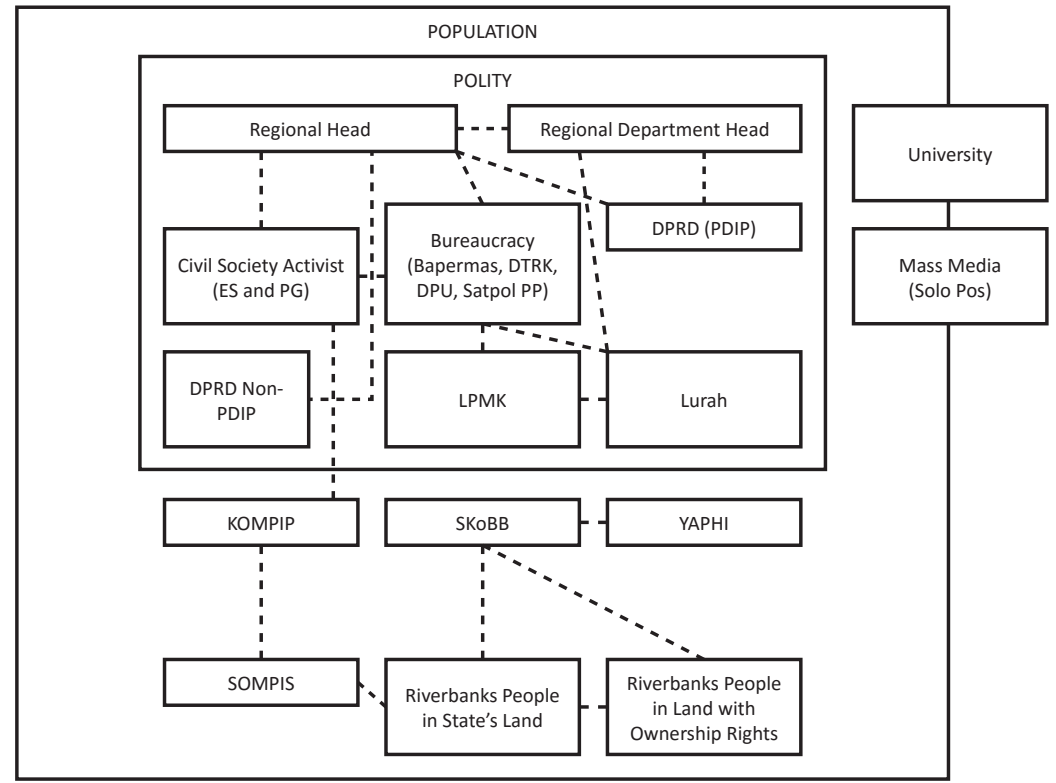

Figure 4. Jokowi's Relation with Multi-actor in Early Stage of Riverbanks Residential Case 


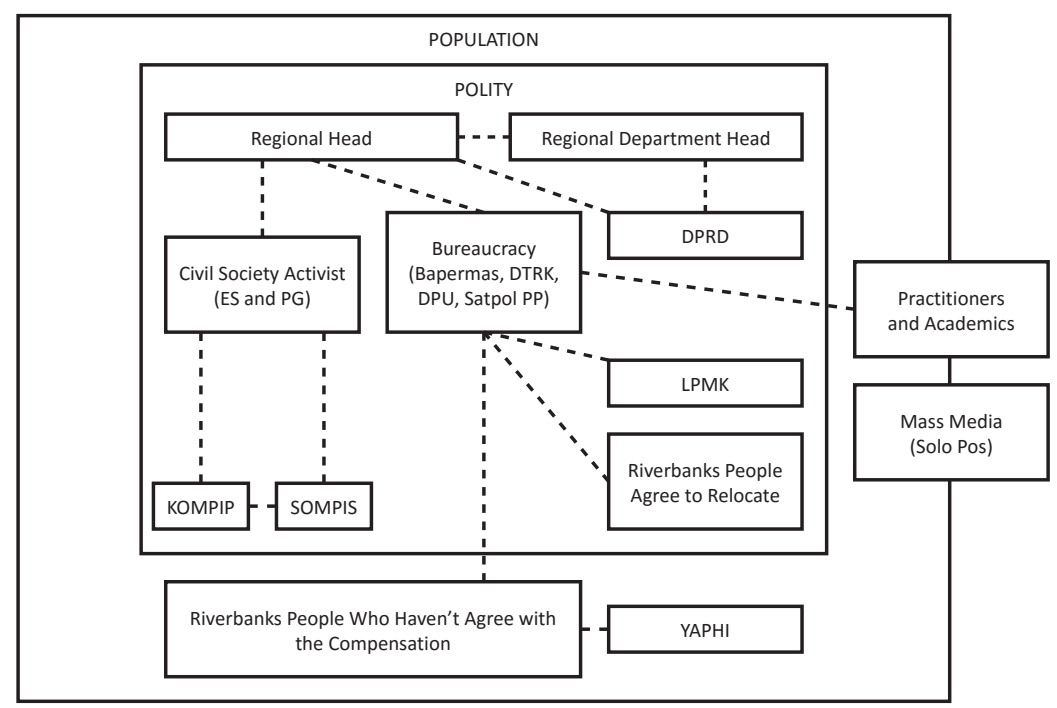

Figure 5. Jokowi's Relation with Multi-actor in Final Stage of Riverbanks Residential Cases

from the source of power, as is done by academics and professionals as well as mass media.

In addition, there are those who play on two feet, namely critical member (as done by the Solo Consortium) and cooperative challenger (as done by KOMPIP). In contrast to the position of the CSA which relation is built to support the work of regional head, Solo Consortium is seen playing on two legs, namely between member and challenger with the tendency as a member. On various occasions, the Solo Consortium hugely support (as actors) the policies of Jokowi, including in the process of increasing participation of sectoral groups in development (musrenbang sectoral issues) as well as mentoring of village development activities by citizens through PPMK fund, which is a continuation of advocacy provision of the previous block grants (in Slamet Suryanto's period) fought by Solo Consortium so that eventually could be developed in Solo. Besides, the personnel of Solo Consortium, namely Remy Samuel Rory, is "placed" in Solo Consortium to oversee poverty reduction policies, by becoming the Secretary of TKPD.

However, a critical attitude of Solo Consortium remains visible, including in the process of street vendor local regulation revision and a critical attitude of TKPKD towards poverty mitigation policies in Solo. TKPKD, for example, developed its own poverty indicators for Solo City based on BPS poverty indicators (become 25 indicators from the existing 14 indicators), with the assumption that more indicators need to be built according to the factual conditions of Solo.

In addition, in many occasions, TKPKD freely exposes the increased of poverty in Solo City, which in some cases can be a sensitive issue because it is associated with the less good performance of local government. In the process of the past Jakarta gubernatorial election, for example, the competitors of Jokowi launched the increasing number of poverty as exposed by TKPKD as evidence of Jokowi's "failure" in building Solo. Therefore, the author supposed that although as a member (as the actors of Jokowi's programs and policies), Solo Consortium actually does not really position itself as a member but also as a challenge, with the dominant position as a member.

Related to the proportion by Tilly (1978) which stated that the relation of the member with the party with the authority to resources due to the consideration that member can access resources, in the context of Jokowi's relation with CSAs, then the resources as mentioned by Tilly are interpreted in the broadest sense. Not only as economic resources, but also in the form of non-material factors among which is the idea of change (change movement). Another factor that is also important is related to Jokowi's willingness to work hard in carrying out his responsibilities as a regional leader, his willingness to be an example of the idea to fight for, as well as the strong commitment shown in the fight for the interests of the poor. It became a magnet that causes the CSAs willing to work to help Jokowi so that Jokowi is not only positioned as having the legal-rational authority with formal authority, but also an actor who has charismatic power and hence deemed worthy of "assisted." Helping Jokowi even considered a "sacred duty," which gives satisfaction (award) the actors.

In addition, if Tilly stated that there will be the possibility of conflict between the member for the contestation of power (fight over influence, fight over more share of the resources), it is not proven on Jokowi's relation with CSA. There is never a conflict between the three CSAs to compete for resources (financial benefit) because the three of 
those do not want to take economic advantage out of the relations. Besides, the conflict does not occur because the CSAs mutually understand each position (contribution) in relation to Jokowi, namely: ES as the discussion companion of Jokowi to political issues, PG for relations with the community and the media given his experience as a reporter, and AN in the context of helping Jokowi in branding Solo.

Eventually, the most important finding of this study is related to the relation with CSA that is proven effective in helping the state to deal with a number of opposition. With the help of CSA, Jokowi is proven able to "tame" challenge, either through the help of experience sharing, the action of technical assistance in field execution, as well as with the expansion of networking (NGO networking). In addition, the support of regional deputy head, who is formally responsible for helping work of regional head, is also proven to be reliable; namely in the form of political power back-up and the ability to "subdue" the radical opposition groups as well as the thugs who interfere with the process of reform.

Regarding the ideal model of the relation between regional head and multi-actors in local reform developed by the author based on the model by Tilly (1978) and the result of the study, it can be seen in Figure 6. As seen in the figure, regional head and regional deputy head are a solid team with relatively equal relationship (partners and not subordinate) given that despite formally deputy regional head is positioned as aiding the task of regional head, in practice he can serve as a strategic member with his political support, energy, and ideas.

Referring to the practice of reform in Solo, one of the strategies to maintain harmonious relations is to do a clear division of roles between the regional head and regional deputy head. Although in Law No. 32/2004 normatively mentioned the main tasks of the regional head and regional deputy head, but in practice, the role executed by regional deputy head is highly dependent on unilateral decisions of the regional head. Therefore, it is no wonder that in practice, there are quite many regional deputy heads whose function is as the spare tire (just become functional when the regional head is not in place or unavailable as stated in Law No. 32/2004 paragraph g) or, if they are given any responsibility, it is just for the type of non-strategic tasks, both politically and administratively (positioned as the "helper" of regional head as mentioned in article 26, paragraphs a and b, of Law No. 32/2004).

With regards to the cases of broken joint venture that have reached the alarming levels (according to Gunawan Fauzi, in 2012 reached 93.85 percent), the factor of regional head's unreadiness to share the authority with the deputy head is one of the reason why the relation between regional head and regional deputy head is often problematic. This is compounded by the attitude of positioning deputy head as the rival for the nomination in the following period, which is often the reason why regional head does "castration" on the role of the regional deputy head. The "searching" process of candidate who often takes place within a very short time (conducted just months before the nomination) and without the process of harmonization between the two (i.e. personal suitability and vision and mission equalization), becomes the reason why the pair of regional head and regional deputy head is not really solid (cohesive) to cooperate in pursuing reform. It is compounded by the basic consideration of a candidacy that is often orientated on tacticalpragmatic interest (electability, popularity, and the candidate's ability to fund campaign activities) instead of the more substantively ideological considerations such the similarity of idealism and vision and mission to be fought.

Referring to the practice in Solo, personality aspect of regional head and deputy regional head actors becomes the factor that influences whether the harmonious relation between the two of them is maintained or not. Although Jokowi and Rudy in some aspects actually have many differences, their combined ability to manage or resolve conflicts enables the tension due to the conflict can be reduced or maintained not to damage their relations. For example, although both Jokowi and Rudy have the tendency to not be bound by formal procedures, but Jokowi and Rudy have different approaches to problem solving. For instance, Jokowi relies more on professional works (handling the tasks to people who are professionally accountable), while Rudy relies more on handling the tasks to someone who has particularly close relations with him and PDIP.

It is understandable given the background of the two is different: Jokowi who was a businessman is familiar with professional work while Rudy who was a long-time functionary of political parties (even became the Chairman of the DPC of PDIP), is orientating towards aspects of political considerations. However, with a clear division of responsibilities, each side (both Jokowi and Rudy) tried to tolerate attitude differences that occur. For the placement of bureaucracy HR in urban villages and district as well as the monitoring and work evaluation of districts and urban villages, for example, Jokowi did not intervene too much and handed over the responsibility completely to Rudy. Jokowi preferred to concentrate on the development agenda with a variety of innovation programs to be developed and will take intervention measures if there is an indication of irregularities or will lead to counter-productive on the reform efforts being developed (the case of mutation issue of subdistrict and village heads by Jokowi who were considered 


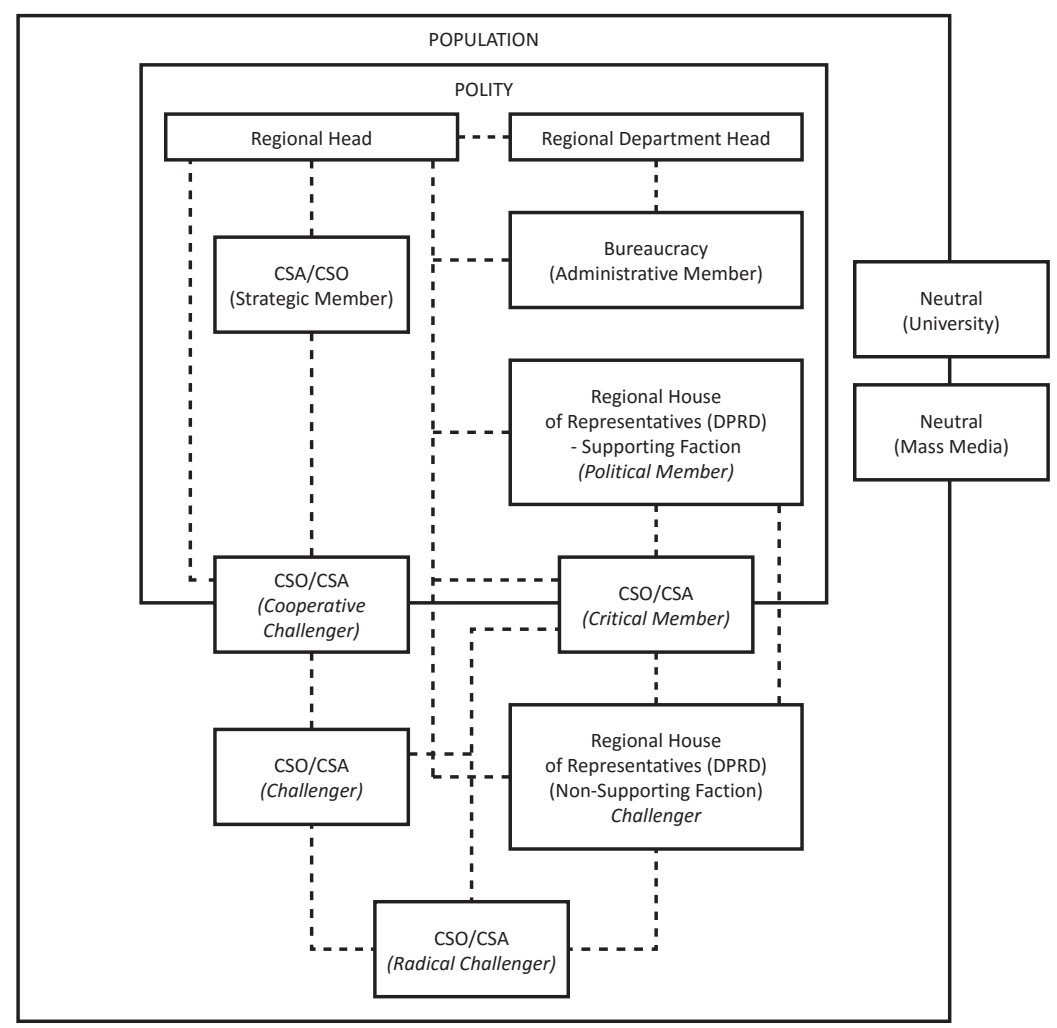

Figure 6. Model of Relations Between Actors in Local Reform

"mbalelo" or disobedient in implementing reform agenda).

Beside regional deputy head, the regional head also needs other strategic members who could be positioned as the inner circle, which can consist of individual actors (CSA, experts, practitioners, and others) as well as institutional actors (NGOs, community organizations, professional organizations, and other civil society organizations). Inner circle originally are those who are willing to work to support the efforts of the regional head to create reform agenda on the foundation of idealism (non-profit oriented), so it can also be referred to as an inner social circle.

The importance of the voluntarism and idealism aspects is significant given the two things, referring to the reform in Solo, are important factors that led to the relation between regional head and a variety of individual actors that are positioned as the inner circle which correlates with the embodiment of the reform agenda. In practice, the inner circle actors of the regional head are generally filled by those who are engaged because of the consideration of political aspects (political inner circle), such as filled with campaign team or party which is considered able to negotiate with region head to promote the interests of supporting a political party. Therefore, the support given by inner political circle is generally more oriented towards political achievements (the capitalization of power), which is not always relevant to the reform objectives, even can be counter-productive in manner.

Bureaucracy as the driving engine of bureaucratic has the position of the inner administrative circle, which gives full support to the administrative aspects of power management. Related to that, the politicization of bureaucracy is better to avoid since it could interfere with the working professionalism of the bureaucratic machine in implementing their basic duty.

Critical members or those who become members but still critical invoices are also required in order to maintain the consistency of the direction of change. Likewise with the cooperative challenger, which is the opposition that wants to open up communication with the government (either directly or through the inner social circle and inner political circle). They are needed to bridge the government with the challenger who tend to oppose the policy. The relation of the cooperative challenger with challenger can help to achieve an agreement (simplify the negotiation process) between the government the challenger, in addition, to helping to catch (understanding) the aspirations of the challenger on government policy. As for the challenger, the relation is important because it can help them understand the objectives and benefits of the policy, as well as the constraints of the government.

DPRD's non-supporting factions generally take 
a position as a challenger. Although the positioning of DPRD's non-supporting factions in Indonesia actually do not really occupy a position of opposition (reject a policy but support other policy), but the presence of DPRD as an opponent needs to be built, despite the refusal must be guarded in the context of checks and balances and not rejection in political nature (politicking). The presence of impartial parties (neutral) in the process of "grabbing" resources because preferring to favor public interest (pro-poor) is also required as the "controller" of the running reform process. This role can be filled by mass media (as the fourth pillar of democracy) and the university as the reference center for knowledge.

Political and economic relations (especially with the purpose of remuneration for the support in the election process) can occur. However, because factually proven to result in transactional politics practices (political cartel) and the strengthening of the political oligarchy, it is better to avoid. Conversely, relation with the member that is built on the spirit of encouraging change (reform agenda embodiment) needs to be developed, because factually (in the case of Solo City) it is proven to be a positive contribution to support local reform.

In more ideal condition, the member of this category will be better if it is managed jointly by the actors of regional head and regional deputy head through an open process (in the determination of who is involved and the reasons for choosing) and can even be done with community involvement (participatory) so "wild" deals of transactional politics can be avoided. Those involved could come from personal networking of the actors of head and deputy head of the region, but my twill is better to be supplemented with public suggestions so that it represents the interests of the wider audience. The concrete form of this member is some kind of senior council or city council, or can also be a discussion forum for city development. Regarding whether the format of the forum or the city council is formal or non-formal, open or closed, flexible or fixed, is highly dependent on regional conditions and specific needs. The principle here is how to make members work productively and effectively in support of the actors of regional heads (and regional deputy head) in creating the reform agenda.

\section{Conclusion}

1. The relation with multi-actors is used by Jokowi as an effort to strengthen his ability in coping with structural constraints, including in the form of budgetary constraints, the availability of regulation, bureaucracy, and institutions readiness (such as the value system that does not support), etc. By developing a relationship with a number of actors, especially the CSO and CSA, the various existing limitations can be minimized. For example, Jokowi's relation with CSA is able to fill the "inability" of the bureaucracy to work fast and work out of the box (innovative) because it is constrained by the existing procedural. The support of CSA overcome the obstacle, enabling more productive bureaucracy in pursuing reform. Non-formal approaches of Jokowi also made easier because he got the "knowledge" regarding the technical implementation through a process of discussion (sharing knowledge) with the CSA, which has been assisting the poor groups in Solo City.

2. Related to the efforts of regional head to enlarge the coalition (enlarge area policy) is characterized by the change of challenger into member (at least, the number of challenger is reduced), both in the case of the arrangement of street vendors, the resettlement of riverbanks residents, as well as in local reform process in general; and it becomes easier because of the following things:

a.The existence of aid from CSA positioned as an inner social circle (true loyalist members) who have no formal relationship with the regional head. CSA's supports among other are manifested in the form of ideas, technical assistance of action workmanship in the field, owned networks, as well as the political support of the forces under its authority. Besides, the existence of CSA which is a respected figure (senior) among NGOs (especially PG and ES) in Solo City, caused the efforts to be easier. Although the two do not specifically condition directly, but with the delivery of information from the authority holder through the oral of CSA, the delivery of information becomes easier and effective to turn into support.

b. The effort to "tame" challenger's opposition also becomes easier because of the suitability (although within certain limits), the agenda of the struggle (the idea of change) between the challenger and Jokowi. Given the problems of poverty (and economic inequality) has long been a chronic problem in Solo City of which occurred because of discriminatory policies as well as the omission of the poor, almost all NGO make poverty, in this case, the fulfillment of economic, educational, and other social rights (ECOSOC) of the poor, the main issue of their claim. Thus, when Jokowi came with the idea of change to defend the poor, the policy did not get any serious rejection except some NGOs with somewhat different views about what they interpret as defending the interests of the poor. For instance in the context of the arrangement of street vendors, they looked at relocating as the action that did not favor the interests of the poor because it got rid of the poor from the city center for the fulfillment of other group's interests (through the policies of city planning, garden making, regional arrangement in locations where the street vendors were previously located). However, because the existence of this 
group was not too significant, it did not become a meaningful distraction.

c.Moreover, because of the tendency of contenders (challenger and member) to coordinate their actions with or without the government's role, the rejection of these groups can be addressed through communication and interaction between them (challenger and member). Moreover, because the challenger and member in Solo City generally know each other given Solo City is relatively small, even they generally have been cooperating as a team (in the era before the leadership of Jokowi).

d. The intervention of various programs from donors led to the maturity of attitude among the activists of civil society (including NGOs) in Solo City, among other is marked by their readiness to accept differences (not lead to conflict, at least open conflict). NGO of Solo City even gather in the "big house" named Solo Consortium, so that efforts to influence the challenger to change their position into member is not a difficult thing to do. Meanwhile, the various community groups and organizations of the poor are also relatively well-organized, which assembled in SOMPIS under the coordination of KOMPIP (NGO).

3. This study enriches the Polity Model (Tilly, 1978) in some of the following things, namely: there are actors who chose neutral position in order to maintain professionalism and neutrality, there are member variants and challenger from the most extreme to the more soft support or opposition, there is challenger who does not want to turn into member because of ideological considerations or because of the availability of alternative resources.

\section{REFERENCES}

Amin, M. 39. Partisipasi Masyarakat dalam Pengelolaan Dana Pembangunan Kelurahan. Retrieved 1 June 2016, from http://www. konsorsiumsolo.com/

Antwi-Boasiako, K. (2010). Dollery, Brian E., and Lorenzo Robotti, eds. The Theory and Practice of Local Government Reform (Book review). International Social Science Review, 85(1-2), 62-63.

Arif, A. 40. Perkuat Kembali Musrenbang, Rayakan Kebersamaan dengan Masyarakat Marginal. Retrieved 31 October 2010, from http://www. kompip.com

Asgart, S. \& Samadhy, W. (2005). Pendulum dari Konsentrasi ke Dekosentrasi. Tempo.

Blau, P. \& Meyer, M. (2000). Birokrasi dalam Masyarakat Modern. Jakarta: Penerbit Prestasi Pustakaraya.

Burns, D., Hambleton, R., \& Hoggett, P. (1994). The Politics of Decentralisation. Basingstoke: Macmillan.

Clark, J., Yuwono, G., \& Umaya, F. (1995). NGO dan
Pembangunan Demokrasi. Yogyakarta: Tiara Wacana.

Constantino-David, K. (1997). Intra-Civil Society Relations. In M. Ferrel, Philippine Democracy Agenda Vol. 3: Civil Society Making Civil Society (1st ed.). Quezon City, Ph.: Third World Studies Center, University of the Phillipines.

Creswell, J. (2003). Research Design: Qualitative, Quantitative, and Mixed Methods Approach (3rd ed.). Thousand Oaks, Calif.: Sage Publications.

Creswell, J. (2007). Qualitative Inquiry and Research Design (2nd ed.). London: SAGE Publications.

Edisi Khusus Kepala Daerah Pilihan 2012. (2012). Teтpo.

Eldridge, P. (1995). Non-Government Organizations and Democratic Participation in Indonesia. New York: Oxford University Press.

Eschborn, N., Hackel, S., \& Richardson, J. (2004). Indonesia Today: Problems and Perspectives: Politics and Society Five Years into Reformasi. Jakarta, Indonesia: Konrad-Adenauer-Stiftung.

Eyermen, R. \& Jamison, A. (1991). Social Movements: A Cognitive Approach. Cambridge, UK: Polity Press.

Fakih, M. (2010). Masyarakat Sipil untuk Transformasi Sosial: Pergolakan Ideologi LSM (5th ed.). Yogyakarta: INSISTPress.

Farrington, J. \& Bebbington, A. (1993). Reluctant partners? Non-Governmental Organizations, the State and Sustainable Agricultural Development. London: Routledge.

Gabris, G., Grenell, K., \& Kaatz, J. (1998). Reinventing Local Government Human Services Management: A Conceptual Analysis. Public Administration Quarterly, 22(1), 74-97.

Ganie-Rochman, M. (2002). An Uphill Struggle: Advocacy NGOs Under Soeharto's New Order. Depok: Lab. Sosio Pusat Kajian Sosiologi FISIP UI.

Gellner, E. (1995). Membangun Masyarakat Sipil: Prasyarat Menuju Kebebasan. Bandung: Mizan.

Giddens, A. (1995). The Constitution of Society: The Outline of the Theory of Structuration. Cambridge, UK: Polity Press.

Goodman, D. (2004). Teori Sosiologi Modern. Jakarta: Prenada Media.

Grindle, M. (2009). Going Local: Decentralization, Democratization, and the Promise of Good Governance. Princeton, NJ [etc.]: Princeton University Press.

Gunawan, J. (2005). Desentralisasi, Globalisasi dan Demokrasi Lokal. Jakarta: LP3ES.

Gunawan, P. (2008). Demokrasi Deliberatif yang Menyejahterakan: Revitalisasi Demokrasi Lokal. Jakarta: Kaukus 17++.

Hadisiswaya, A. (2011). Pergolakan Raja Mataram (2nd ed.). Yogyakarta: Interprebook.

Hadiwinata, B. (2003). The Politics of NGOs in 
Indonesia. London: RoutledgeCurzon.

Hardojo, A. (2008). Mendahulukan Si Miskin : Buku Sumber bagi Anggaran Pro Rakyat. Yogyakarta: Prakarsa.

Harriss, J., Stokke, K., \& Törnquist, O. (2005). Politisasi Demokrasi Politik Lokal Baru. Jakarta: Penerbit Demos.

Hines, C. (2005). Mengganti Globalisasi Ekonomi menjadi Lokalisasi Demokrasi. Yogyakarta: INSIST press.

Janoski, T. (2005). The Handbook of Political Sociology. New York: Cambridge.

Joko Widodo, Walikota Surakarta: Wali Kaki Lima. (2008). Tempo, 37(44).

Kumorotomo, W. \& Pramusinto, A. (2009). Governance Reform di Indonesia: Mencari Arah Kelembagaan Politik yang Demokratis dan Birokrasi yang Profesional. Jakarta: Kerjasama Penerbit Gava Media [dan] MAP-UGM.

LIPI,. (1993). Demokrasi Politik, Makalah Seminar Perkembangan Demokrasi di Indonesia Sejak 1945. Jakarta: Widyagraha, LIPI.

LPPM UNS,. (2005). Laporan Penelitian Hibah Bersaing Tahun I. Surakarta: LPPM UNS.

LPPM UNS,. (2006). Laporan Penelitian Hibah Tahun II. Surakarta: LPPM UNS.

Marijan, K. (2006). Demokratiasasi di Daerah: Pelajaran dari Pilkada Secara Langsung. Surabaya: Pustaka Eureka.

Maula, M. \& A.F., F. (2001). Ngesuhi deso sak kukuban: Lokalitas, Pluralism, Modal Sosial Demokrasi. Yogyakarta: LKIS.

McClosky, H. (1972). Political Participation, International Encyclopedia of The Social Sciences, (2nd ed.). New York: The MacMillan Company and The Free Press.

Ministry of Communication and Informatics, City Gov. of Surakarta,. (2007). Memboyong 989 PKL: Dari Banjarsari ke Semanggi. Solo: Ministry of Communication and Informatics, City Gov. of Surakarta.

Mustafa, A. (2008). Transformasi Sosial Sektor Informal: Sejarah, Teori, dan Praksis Pedagang Kaki Lima. Malang: In-Trans Publishing; INSPIRE.

Nordholt, H. \& van Klinken, G. (2007). Politik Lokal di Indonesia. Jakarta: Yayasan Obor Indonesia.

Prasetyantoko, A., Budiantoro, S., \& Bahagijo, S. (2016). Pembangunan Inklusif: Prospek dan Tantangan. Jakarta: Perkumpulan Prakarsa.

Qomarun, \& Prayitno, B. (2007). Morfologi Kota Solo Tahun 500-2000. Dimensi Teknik Arsitektur, 35(1).

Rahayu, M. \& Rutiana, D. (2007). Strategi Perencanaan Pembangunan Permukiman Kumuh, Kasus Pemukiman Bantaran Sungai Bengawan Solo, Kelurahan Pucang Sawit, Surakarta. Gema Teknik, 1(10).
Rifai, A., Gunawan, P., \& Bachry, S. (2009). Geliat Partisipasi Kelompok Sektoral: Studi Kasus Kota Surakarta. In Suhirman, Partisipasi, Reformasi Kelembagaan, dan Alokasi Anggaran: Pembelajaran dari Lima Daerah (1st ed.). Jakarta: FPPM.

Ritzer, G. (1996). Modern Sociological Theory (4th ed.). Boston: McGraw Hill International.

Ritzer, G. \& Goodman, D. (1996). Sociology Theory (6th ed.). Boston: McGraw Hill International.

Salamm, A. (2007). Desentralisasi \& Otonomi Daerah: Desentralisasi, Demokratisasi \& Akuntabilitas Pemerintah Daerah. Jakarta: LIPI Press.

Samrono, I. (2010). Daerah Istimewa Surakarta: Wacana Pembentukan Propinsi Daerah Istimewa Surakarta Ditinjau dari Perspektif Historis, Sosiologis, Filosofis, dan Yuridis. Yogyakarta: Pura Pustaka.

Samuel, H. \& Nordholt, H. (2004). Indonesia in Transition: Rethinking 'Civil Society', 'Region', and 'Crisis.' Yogyakarta: Pustaka Pelajar.

Sedikit Orang Baik di Republik yang Luas. (2008). Tempo, 37(44).

Siraishi, T. (2005). Zaman Bergerak: Radikalisme Rakyat di Jawa Tengah 1912-1926. Jakarta: Grafiti.

Sobari, W. (2004). Inovasi Referensi: Tiga Tahun Otonomi Daerah dan Otonomi Award. Jakarta: Partnership.

Stiftung, B. (2010). Sustainable Governance indicators 2009: Policy Performance and Executive Capacity in the OECD. Guetersloh: Verlag Bertelsmann Stiftung.

Sugiartoto, A. (2003). Perencanaan Pembangunan Parsitipatif Kota Surakarta: Pendekatan Pembangunan Nguwongke-Uwong. Surakarta: IPGI.

Suharko,. (2005). Merajut Demokrasi: Hubungan NGO, Pemerintah, dan Pengembangan Tata Pemerintahan Demokratis (1966-2001). Yogyakarta: Tiara Wacana.

Sumarto, H. (2009). Inovasi, Partisipasi, dan Good Governance: 20 Prakarsa Inovatif dan Partisipatif di Indonesia. Jakarta: Yayasan Obor Indonesia.

Suwondo, K. (2005). Civil Society di aras Lokal: Perkembangan Hubungan antara Rakyat (2nd ed.). Salatiga: Pustaka Percik.

Tilly, C. (1978). From Mobilization to Revolution. New York: Random House.

Tjandra, W. (2005). Peningkatan Kapasitas Pemerintah Daerah dalam Pelayanan Publik. Jakarta: Pembaruan.

Triwibowo, D. (2002). Gerakan Sosial: Wahana Civil Society bagi Demokratisasi. Jakarta: LP3ES \& Perkumpulan Prakarsa.

Turner, J. (1990). The Structure of Sociological Theory. California: Wadsworth Publishin 
Company.

Turner, M. \& Podger, O. (2003). Decentralization in Indonesia: Redesigning the State. Canberra: Asia Pacific Press Asia Pacific School of Economics and Government the Australia National University.

van Ufford, P. \& Giri, A. (2009). Kritik Moral Pembangunan. Jakarta: Kanisius.

Wallis, J. \& Dollery, B. (2005). The Impact of Alternative Styles of Policy Leadership on the Direction of Local Government Reform. International Journal of Social Economics,
32(4), 291.

Wibawa, S. (2009). Evaluasi Kebijakan Publik. Jakarta: PT. RajaGrafindo Persada.

Yin, R. (2002). Studi Kasus Desain \& Metode. Jakarta: PT. RajaGrafindo Persada.

Zuhro, R. (2009). Demokrasi Lokal: Peran Aktor dalam Demokratisasi. Yogyakarta: Peerbit Ombak.

Zuhro, R. (2009). Demokrasi Lokal: Perubahan dan Kesinambungan Nilai-nilai Budaya Politik Lokal di Jawa Timur, Sumatera Barat, Sulawesi Selatan, dan Bali. Yogyakarta: Penerbit Ombak. 